\title{
The in Vivo Effect of Cordyceps sinensis Mycelium on Plasma Corticosterone Level in Male Mouse
}

\author{
Sew-Fen Leu, ${ }^{a}$ Chi-Hsien Chien, ${ }^{b}$ Chi-Yu Tseng, ${ }^{b}$ Yu-Ming Kuo, ${ }^{b}$ and Bu-Miin Huang ${ }^{*}, b$ \\ ${ }^{a}$ National Laboratory Animal Breeding and Research Center, National Science Council, Taipei, Taiwan, Republic of \\ China : and ${ }^{b}$ Department of Cell Biology and Anatomy, College of Medicine, National Cheng Kung University; Tainan, \\ Taiwan, 70101 Republic of China. Received May 2, 2005; accepted June 2, 2005
}

Cordyceps sinensis (CS), an Ascomycetes fungus parasitic to Lepidoptera larvae, has been traditionally used as nutritious food for the enhancement in immuno-modulation in Chinese society for a long time. Previous report has demonstrated the CS water extract stimulates in vitro corticosterone production in rat primary adrenal cells. In the present studies, we determined the in vivo effects of $C S$ and its fractions on plasma corticosterone production in mouse. Different concentrations of CS and CS fractions dissolved in water $(0.02$ and $0.2 \mathrm{mg} / \mathrm{g}$ body weight) were fed to immature and mature mice from 1,3 or $7 \mathrm{~d}$. The plasma levels of corticosterone were determined by radioimmunoassay (RIA), and the weight of adrenal gland and body weight were also evaluated. Results illustrated that plasma corticosterone levels were significantly induced by $F 2$ at $0.02 \mathrm{mg} / \mathrm{g}$ body weight with $7 \mathrm{~d}$ feeding in immature mice, and by CS at $0.02 \mathrm{mg} / \mathrm{g}$ body weight with $3 \mathrm{~d}$ feeding and $\mathrm{F3}$ at $0.02 \mathrm{mg} / \mathrm{g}$ body weight for $7 \mathrm{~d}$ feeding in mature mice, respectively $(p<0.05)$. There were no differences of adrenal gland weight except there was significant stimulation by $\mathrm{CS}$ at $0.2 \mathrm{mg} / \mathrm{g}$ body weight with $3 \mathrm{~d}$ feeding in mature mice $(p<0.05)$ and there were significant inhibitions by both dosages of $F 3$ for $3 \mathrm{~d}$ feeding in immature mice and $F 2$ for $7 \mathrm{~d}$ feeding in mature mice $(p<0.05)$, respectively. Concerning body weight, the stimulatory effects were observed with CS feeding at $0.2 \mathrm{mg} / \mathrm{g}$ body weight for $7 \mathrm{~d}$ and $\mathrm{F} 3$ feeding at $0.02 \mathrm{mg} / \mathrm{g}$ body weight for 3 and $7 \mathrm{~d}$ in mature mice. Whereas, the inhibitory effect were observed in $F 2$ feeding at $0.2 \mathrm{mg} / \mathrm{g}$ body weight for $7 \mathrm{~d}$ in immature mice and at both dosages for $7 \mathrm{~d}$ in mature mice, respectively. Taken together, these studies illustrate that CS and its fractions stimulated mouse in vivo corticosterone production. However, CS and its fractions didn't have constant stimulatory or inhibitory effects on the weights of body and adrenal glands.

Key words Cordyceps sinensis (CS); adrenal gland; corticosterone; mouse; in vivo

Cordyceps sinensis (CS) is an Ascomycetes fungus parasitic to Lepidoptera larvae, and has long been used as medicine to treat many illnesses and promote longevity in Chinese society. ${ }^{1,2)}$ Previous investigations have shown that CS has many pharmacological activities such as reducing mean arterial pressure, ${ }^{3)}$ preventing cholesterol deposition in aorta, ${ }^{4)}$ and inducing tumor programmed cell death. ${ }^{5-8)}$ Moreover, reports have also demonstrated that CS can suppress tumor cell growth, modulate immune response, ${ }^{9-11)}$ stimulate the activity of natural killer cells and macrophages with anti-inflammatory effect, ${ }^{12,13)}$ and inhibits rejection of organ transplants, which is possible that the effect of CS on the immune system is mediated via hormonal secretion by the adrenal cortex since its product, glucocorticoid, is a favorite candidate for immuno-suppression. ${ }^{14)}$ Indeed, it has been demonstrated that CS can promote sex hormones in Leydig cells in vitro and in vivo ${ }^{15-20)}$ and adrenal cells in vitro. ${ }^{21)}$ It is well known that adrenocorticotropin (ACTH) will bind to membrane receptor of adrenal cells to trigger steroidogenesis. ${ }^{22}$ Aim of this study is to examine if CS would also induce in vivo effects on corticosterone production in mouse. In addition, it remains to be clarified whether CS fractions will also have the effect. Thus, mice were fed with CS and its fractions (F2 and F3) and the in vivo plasma corticosterone levels and weights of body and adrenal glands were determined in the present study.

\section{MATERIALS AND METHODS}

Chemicals Culture mycelium of CS was supplied by the Simpson Biotech Co. Ltd. (Taipei, Taiwan). Ether, ethanol, charcoal and corticosterone were purchased from Sigma Chemical Co. (St. Louis, MO, U.S.A.). ${ }^{3} \mathrm{H}$-Corticosterone was purchased from DuPont-New England Nuclear (Boston, MA, U.S.A.). Antiserum to corticosterone was a gift from Dr. Paulus S. Wang (National Yang-Ming University, Taipei, Taiwan).

Preparation of CS Fractions One hundred grams of crude CS was extracted with $800 \mathrm{ml}$ distilled water and shaken at $37^{\circ} \mathrm{C}$ for $72 \mathrm{~h}$. The solution was then centrifuged at $12000 \times \boldsymbol{g}$ at $4{ }^{\circ} \mathrm{C}$ for $30 \mathrm{~min}$ to collect the pellet named fraction $3(\mathrm{~F} 3)$. The supernatant was applied in the G150 gel filtration column $(3 \times 100 \mathrm{~cm})$ with $50 \mathrm{~mm} \mathrm{CH}_{3} \mathrm{COONH}_{4}$ buffer at $\mathrm{pH}$ 6.0. Two peaks were collected; the first peak was designated F1 and the second peak, F2. The yield percentage of F1, F2, and F3 were $1.69 \%, 13.46 \%$, and $84.85 \%$, respectively. The main content of those CS fractions were F2 with water-soluble low molecular weight proteins and F3 with relatively poor water-soluble polysaccharides and proteins.

Animals Male B6 (C57BL/6NCrj) mice, 4-5 weeks old, were purchased form NCKUAC (National Cheng Kong University Animal Center). All animals were housed in groups of $4-6$ in $29 \times 18 \times 13-\mathrm{cm}$ polyethylene cages. The animal room was maintained at $22-24^{\circ} \mathrm{C}$ on a $12: 12 \mathrm{~h}$ light: dark cycle. Purina mouse chow (Ralston-Purina, St. Louis, MO, U.S.A.) and water were always available. Animals were randomly divided into three groups, at least 5 in each group, with the infusions of water, 0.02 or $0.2 \mathrm{mg} / \mathrm{g}$ body weight of CS, F2 or F3, respectively, for 1, 3 or $7 \mathrm{~d}$. The age at the beginning of experiment was 5 weeks old for immature mice and was 10 weeks old for mature mice. Animals were killed by cervical dislocation and trunk blood was col- 
lected. The blood samples were kept on ice until the end of the study when they were centrifuged for $1 \mathrm{~min}$ at $12000 \times \boldsymbol{g}$ to separate plasma. Serum was collected and stored at $-20^{\circ} \mathrm{C}$ until assayed for corticosterone by radioimmunoassay. Weights of body and adrenal gland were also collected and weighted.

Radioimmunoassay Corticosterone levels in plasma were determined by established radioimmunoassay after $5 \mu \mathrm{l}$ plasma samples were diluted to $250 \mu \mathrm{l}$ and extracted with $5 \mathrm{ml}$ ether (Sigma Chemical Co., St. Louis, MO, U.S.A.). Recovery after ether extraction averaged $85 \%$. Twenty-five microliters of ether with extracted plasma was put into tube and blown try, and $100 \mu \mathrm{l}$ of corticosterone antiserum and $100 \mu \mathrm{l}$ of ${ }^{3} \mathrm{H}$-corticosterone were added. Equilibrium reaction occurred at room temperature for $2 \mathrm{~h}$ and was stopped by putting the tubes in ice. Charcoal was added and incubated for $15 \mathrm{~min}$ at $4{ }^{\circ} \mathrm{C}$ and then centrifuged for $10 \mathrm{~min}$ to spin down the charcoal bound with free ${ }^{3} \mathrm{H}$-steroids. The supernatant was poured into $3 \mathrm{ml}$ of scintillation fluid and samples were counted in $\beta$-counter for 2 min. $^{23)}$

Statistics Each data point in the figures represents the mean \pm S.E.M. of plasma corticosterone production, body weight and adrenal gland weight of at least 5 mice. Statistically significant differences between treatments and controls were determined by one-way ANOVA and the Fisher-PLSD multiple comparison procedure. Statistical significance was set at $p<0.05$.

\section{RESULTS}

The Effect of CS on Plasma Corticosterone Levels, Body Weight and Adrenal Gland Weight in Immature and Mature Mice In the present experiment, immature and mature mice were used to examine if there is difference of corticosterone production responding to $\mathrm{CS}$ and its fractions. Thus, immature mice were fed with CS mycelium for 3 or $7 \mathrm{~d}$, and corticosterone levels and weights of body and adrenal gland were determined. There were no significant difference of the plasma corticosterone production with the feeding of 0.02 and $0.2 \mathrm{mg} / \mathrm{g}$-body weight of CS for 3 and $7 \mathrm{~d}$ compared to control in immature mice $(p>0.05)$ (Table 1). Similarly, feeding of CS at both dosages for 3 and $7 \mathrm{~d}$ didn't have any effect on the weights of body (Table 1) and adrenal gland (Table 1) $(p>0.05)$.

Mature mice were fed with CS mycelium for 3 or $7 \mathrm{~d}$, and corticosterone levels and weights of body and adrenal gland were determined. Corticosterone production was significantly stimulated by the feeding of $0.02 \mathrm{mg} / \mathrm{g}$-body weight of $\mathrm{CS}$ for $3 \mathrm{~d}(p<0.05)$. There were no significant differences by $\mathrm{CS}$ at $0.2 \mathrm{mg} / \mathrm{g}$-body weight for $3 \mathrm{~d}$ or both doses for $7 \mathrm{~d}$ compared to control in mature mice (Table 1) $(p>0.05)$. The feeding of CS at $0.2 \mathrm{mg} / \mathrm{g}$-body weight for $7 \mathrm{~d}$ had significantly stimulatory effect on body weight (Table 1), and the feeding of CS at $0.2 \mathrm{mg} / \mathrm{g}$-body weight for $3 \mathrm{~d}$ had significant stimulatory effect on the weight of adrenal gland in mature mice (Table 1) $(p<0.05)$.

The Effect of F2 on Plasma Corticosterone Levels, Body Weight and Adrenal Gland Weight in Immature and Mature Mice $\mathrm{We}$ have shown that $\mathrm{F} 2$ and F3 mycelium extracts, but not F1, were able to induce in vitro primary Leydig cell steroidogenesis, respectively. ${ }^{17)}$ Thus, F2 and F3 were used to feed mice to determine if corticosterone production would also be affected in the present study. Thus, immature mice were fed with F2 mycelium extract for 1, 3 or $7 \mathrm{~d}$, and corticosterone levels and weights of body and adrenal gland were determined. Results illustrate that only the plasma corticosterone level was significantly induced by F2 at $0.02 \mathrm{mg} / \mathrm{g}$-body weight compared to control (Table 2), whereas only the body weight was reduced by F2 at $0.2 \mathrm{mg} / \mathrm{g}$-body weight for $7 \mathrm{~d}$ compared to control (Table 2) $(p<0.05)$. Besides, there were no effects of $\mathrm{F} 2$ feeding at 0.02 and $0.2 \mathrm{mg} / \mathrm{g}$-body weight for 1,3 and $7 \mathrm{~d}$ on plasma

Table 1. The Effects of CS Feeding for 3 or $7 \mathrm{~d}$ on Plasma Corticosterone Levels, Body Weight and Adrenal Gland Weight in Immature and Mature Mice

\begin{tabular}{|c|c|c|c|c|c|c|c|c|c|c|}
\hline & & \multicolumn{3}{|c|}{ Corticosterone $(\mathrm{pg} / \mu \mathrm{l})$} & \multicolumn{3}{|c|}{ Body weight (g) } & \multicolumn{3}{|c|}{ Adrenal weight (mg) } \\
\hline & & Control & $0.02 \mathrm{mg}$ & $0.2 \mathrm{mg}$ & Control & $0.02 \mathrm{mg}$ & $0.2 \mathrm{mg}$ & Control & $0.02 \mathrm{mg}$ & $0.2 \mathrm{mg}$ \\
\hline \multirow[t]{2}{*}{ Immature } & $3 \mathrm{~d}$ feeding & $132.0 \pm 45.6$ & $136.0 \pm 23.7$ & $143.7 \pm 38.5$ & $16.2 \pm 0.2$ & $17.9 \pm 0.4$ & $17.7 \pm 0.4$ & $1.9 \pm 0.1$ & $1.9 \pm 0.1$ & $1.8 \pm 0.1$ \\
\hline & $7 \mathrm{~d}$ feeding & $233.9 \pm 90.8$ & $199.2 \pm 43.7$ & $215.0 \pm 58.3$ & $16.9 \pm 0.2$ & $16.1 \pm 0.6$ & $17.1 \pm 0.5$ & $1.9 \pm 0.1$ & $1.9 \pm 0.1$ & $1.9 \pm 0.0$ \\
\hline \multirow[t]{2}{*}{ Mature } & $3 \mathrm{~d}$ feeding & $149.5 \pm 26.1^{a)}$ & $261.0 \pm 35.4^{b)}$ & $199.4 \pm 7.8^{a)}$ & $24.7 \pm 0.9^{a, b)}$ & $23.6 \pm 0.6^{a)}$ & $26.5 \pm 0.4^{b)}$ & $1.9 \pm 0.1^{a)}$ & $1.9 \pm 0.1^{a)}$ & $2.2 \pm 0.1^{b)}$ \\
\hline & $7 \mathrm{~d}$ feeding & $215.5 \pm 30.6$ & $230.9 \pm 44.5$ & $319.5 \pm 44.5$ & $\left.22.1 \pm 0.6^{a}\right)$ & $22.4 \pm 0.3^{a)}$ & $25.2 \pm 0.5^{b)}$ & $1.9 \pm 0.1$ & $1.8 \pm 0.1$ & $1.9 \pm 0.1$ \\
\hline
\end{tabular}

Each value shown represents the mean \pm S.E.M. of plasma corticosterone production, body weight and adrenal gland weight of at least 5 mice. $a$ ) and $b$ ) indicate $p<0.05$ compared between control or CS feedings in different treatments.

Table 2. The Effects of F2 Feeding for 1, 3 or $7 \mathrm{~d}$ on Plasma Corticosterone Levels, Body Weight and Adrenal Gland Weight in Immature and Mature Mice

\begin{tabular}{|c|c|c|c|c|c|c|c|c|c|c|}
\hline & & \multicolumn{3}{|c|}{ Corticosterone $(\mathrm{pg} / \mu \mathrm{l})$} & \multicolumn{3}{|c|}{ Body weight (g) } & \multicolumn{3}{|c|}{ Adrenal weight (mg) } \\
\hline & & Control & $0.02 \mathrm{mg}$ & $0.2 \mathrm{mg}$ & Control & $0.02 \mathrm{mg}$ & $0.2 \mathrm{mg}$ & Control & $0.02 \mathrm{mg}$ & $0.2 \mathrm{mg}$ \\
\hline \multirow[t]{3}{*}{ Immature } & $1 \mathrm{~d}$ feeding & $208.4 \pm 51.8$ & $240.0 \pm 29.2$ & $278.5 \pm 56.5$ & $18.4 \pm 0.2$ & $19.3 \pm 0.4$ & $18.5 \pm 0.2$ & $1.8 \pm 0.0$ & $1.8 \pm 0.1$ & $1.7 \pm 0.1$ \\
\hline & $3 \mathrm{~d}$ feeding & $167.6 \pm 51.2$ & $222.2 \pm 12.8$ & $164.0 \pm 12.8$ & $19.5 \pm 0.7$ & $18.2 \pm 0.7$ & $19.6 \pm 0.4$ & $1.9 \pm 0.1$ & $1.9 \pm 0.1$ & $1.9 \pm 0.1$ \\
\hline & $7 \mathrm{~d}$ feeding & $163.5 \pm 27.2^{a)}$ & $287.7 \pm 17.0^{b)}$ & $183.0 \pm 31.1^{a)}$ & $20.1 \pm 0.4^{a)}$ & $19.9 \pm 0.2^{a)}$ & $18.6 \pm 0.2^{b)}$ & $1.8 \pm 0.1$ & $1.9 \pm 0.1$ & $1.8 \pm 0.1$ \\
\hline \multirow[t]{2}{*}{ Mature } & $3 \mathrm{~d}$ feeding & $208.3 \pm 39.0^{a, b)}$ & $278.6 \pm 46.3^{a)}$ & $136.1 \pm 36.5^{b)}$ & $25.0 \pm 0.9$ & $23.6 \pm 0.1$ & $23.7 \pm 0.4$ & $2.0 \pm 0.1$ & $1.8 \pm 0.1$ & $1.8 \pm 0.0$ \\
\hline & $7 \mathrm{~d}$ feeding & $198.0 \pm 35.4^{a, b)}$ & $260.1 \pm 15.6^{a)}$ & $138.6 \pm 36.2^{b)}$ & $25.6 \pm 0.4^{a}$ & $22.9 \pm 0.3^{b)}$ & $24.4 \pm 0.3^{c)}$ & $2.0 \pm 0.1^{a)}$ & $1.6 \pm 0.1^{b)}$ & $1.8 \pm 0.1^{a, b)}$ \\
\hline
\end{tabular}

Each value shown represents the mean \pm S.E.M. of plasma corticosterone production, body weight and adrenal gland weight of at least 5 mice. $a$ ), $b$ ) and $c$ ) indicate $p<0.05$ compared between control or CS feedings in different treatments. 
Table 3. The Effects of F3 Feeding for 1,3 or 7 d on Plasma Corticosterone Levels, Body Weight and Adrenal Gland Weight in Immature and Mature Mice

\begin{tabular}{|c|c|c|c|c|c|c|c|c|c|c|}
\hline & & \multicolumn{3}{|c|}{ Corticosterone $(\mathrm{pg} / \mu \mathrm{l})$} & \multicolumn{3}{|c|}{ Body weight (g) } & \multicolumn{3}{|c|}{ Adrenal weight (mg) } \\
\hline & & Control & $0.02 \mathrm{mg}$ & $0.2 \mathrm{mg}$ & Control & $0.02 \mathrm{mg}$ & $0.2 \mathrm{mg}$ & Control & $0.02 \mathrm{mg}$ & $0.2 \mathrm{mg}$ \\
\hline \multirow[t]{3}{*}{ Immature } & $1 \mathrm{~d}$ feeding & $217.1 \pm 71.6$ & $247.9 \pm 70.7$ & $191.0 \pm 25.2$ & $19.5 \pm 0.1^{a, b)}$ & $18.7 \pm 0.5^{a)}$ & $20.3 \pm 0.2^{b)}$ & $2.0 \pm 0.1$ & $2.1 \pm 0.2$ & $1.8 \pm 0.1$ \\
\hline & $3 \mathrm{~d}$ feeding & $347.6 \pm 85.3$ & $297.2 \pm 57.8$ & $310.2 \pm 93.5$ & $17.6 \pm 0.5$ & $18.6 \pm 0.2$ & $18.9 \pm 0.4$ & $2.5 \pm 0.1^{a)}$ & $2.1 \pm 0.4^{a, b)}$ & $1.9 \pm 0.1^{b)}$ \\
\hline & $7 \mathrm{~d}$ feeding & $263.4 \pm 49.5$ & $246.7 \pm 57.6$ & $334.9 \pm 98.8$ & $18.8 \pm 0.4^{a)}$ & $17.8 \pm 0.1^{a, b)}$ & $17.5 \pm 0.3^{b)}$ & $1.8 \pm 0.1$ & $1.7 \pm 0.1$ & $2.1 \pm 0.3$ \\
\hline \multirow[t]{2}{*}{ Mature } & $3 \mathrm{~d}$ feeding & $253.3 \pm 43.9^{a, b)}$ & $141.6 \pm 20.9^{a)}$ & $277.1 \pm 52.7^{b)}$ & $23.8 \pm 0.6^{a)}$ & $26.0 \pm 0.7 b$ & $23.1 \pm 0.1^{a)}$ & $2.0 \pm 0.1^{a, b)}$ & $2.1 \pm 0.1^{a)}$ & $1.8 \pm 0.1^{b)}$ \\
\hline & $7 \mathrm{~d}$ feeding & $213.7 \pm 37.4^{a)}$ & $400.8 \pm 20.8^{b)}$ & $227.9 \pm 36.0^{a)}$ & $21.7 \pm 0.4^{a)}$ & $23.4 \pm 0.3^{b)}$ & $22.6 \pm 0.1^{a, b)}$ & $1.7 \pm 0.1$ & $1.9 \pm 0.1$ & $1.9 \pm 0.1$ \\
\hline
\end{tabular}

Each value shown represents the mean \pm S.E.M. of plasma corticosterone production, body weight and adrenal gland weight of at least 5 mice. $a$ ) and $b$ ) indicate $p<0.05$ compared between control or CS feedings in different treatments.

corticosterone releases and weights of body and adrenal gland (Table 2) compared to control in immature mice $(p>0.05)$.

Mature mice were fed with F2 mycelium extract for 3 or $7 \mathrm{~d}$, and corticosterone levels and weights of body and adrenal gland were determined. There were no differences of plasma corticosterone level between control and treatments for 3 or $7 \mathrm{~d}$ feeding of F2 (Table 2) $(p>0.05)$. Body weight was significantly reduced with the feeding of F2 of both dosages for $7 \mathrm{~d}$ (Table 2) $(p<0.05)$. The weight of adrenal gland was significantly reduced with the feeding of F2 at $0.02 \mathrm{mg} / \mathrm{g}$-body weight for $7 \mathrm{~d}$ (Table 2) $(p<0.05)$.

The Effect of F3 on Plasma Corticosterone Levels, Body Weight and Adrenal Gland Weight in Immature and Mature Mice Immature mice were fed with F3 mycelium extract for 1,3 or $7 \mathrm{~d}$, and corticosterone levels and weights of body and adrenal gland were determined. Results illustrate that only the body weight and the adrenal gland were significantly reduced by $\mathrm{F} 2$ at $0.2 \mathrm{mg} / \mathrm{g}$-body weight for $7 \mathrm{~d}$ and $\mathrm{F} 2$ at $0.2 \mathrm{mg} / \mathrm{g}$-body weight for $3 \mathrm{~d}$, respectively, compared to control (Table 3) $(p<0.05)$. Besides, there were no effects of F3 feeding at 0.02 and $0.2 \mathrm{mg} / \mathrm{g}$ body weight for 1,3 and $7 \mathrm{~d}$ on plasma corticosterone releases and weights of body and adrenal gland compared to control in immature mice (Table 3) $(p>0.05)$.

Mature mice were fed with F3 mycelium extract for 3 or $7 \mathrm{~d}$, and corticosterone levels and weights of body and adrenal gland were determined. Corticosterone production was significantly stimulated by $0.02 \mathrm{mg} / \mathrm{g}$-body weight of F3 for $7 \mathrm{~d}$ (Table 3$)(p<0.05)$. Body weights were also significantly stimulated by $0.02 \mathrm{mg} / \mathrm{g}$-body weight of F3 for 3 and $7 \mathrm{~d}$, respectively (Table 3$)(p<0.05)$. However, there were no differences of adrenal gland with the feeding of F3 at both dosages for 3 and $7 \mathrm{~d}$ compared to control in mature mice (Table 3) $(p>0.05)$.

\section{DISCUSSION}

It has been illustrated that CS extract could induce in vitro corticosterone production in primary adrenal cells. ${ }^{21)}$ The in vivo effect of CS on corticosterone production remains elusive. Thus, the in vivo effect of CS and its fractions on corticosterone production in the plasma of rodent was examined in the present study. We found that $\mathrm{CS}$ and its fractions did induce plasma corticosterone levels in immature and mature mice. However, CS and its fractions had stimulatory or inhibitory effects on body weights and adrenal gland weights, depending on the dosage or length of feeding time by CS or its fractions.

In the present studies, F2 at $0.02 \mathrm{mg}$ of $7 \mathrm{~d}$ feeding had stimulatory effect on corticosterone production in immature mice, which was not shown in mature mice. In contrast, CS and F3, but not F2, did have stimulatory effect only on mature mice. These data imply that different components in CS, F2 and F3 might be diverse, and the responses between immature and mature mice were miscellaneous to CS and its fractions. It has been shown that factors have dissimilar effects between various maturity and age animals. ${ }^{24-26)}$ Thus, it will not be too uncommon with these diverse responses by different components of CS and its fractions on in vivo corticosterone reactions. The finer purification from CS will be necessary to further determine those different reactions.

It is interesting that CS, F2 and F3 had uncorrelated responses concerning body weights and adrenal gland weights to corticorsterone production, and the effects of those materials to body and adrenal gland weights between mature or immature mice were not consistent with the occurrence of stimulation or inhibition. Basically, CS positively induced body and adrenal gland weights in mature mice. In contrast, F2 only reduced body weight in immature mice and both body and adrenal gland weights in mature mice. It is more intriguing that $\mathrm{F} 3$ reduced body and adrenal gland weights in immature mice whereas F3 induced body weights, but not adrenal gland, in mature mice. It has been shown that stress will induce in vivo glucocorticoid releases, which will then induce various reactions, such as behaviors and the changes of body and adrenal gland weights. ${ }^{27-31)}$ Therefore, our findings were not unprecedented. However, the mechanisms related to the different or even opposite responses by CS, F2 and F3 regarding glucocorticoid releases, body and/or adrenal gland weights in mice will be worth to be investigated. It is possible that the understanding of the mechanism can be exploited for the health food or alternative medicines to do goodness on our body.

In some results, higher dose of CS and its fractions did not have responses in corticorsterone production, body and/or adrenal gland weights, which indicated that lower dose of CS and its fractions was in the optimal function to induce the reactions. It is well known that hormonal factors at certain dosages always have the optimal effect on endocrine system and higher dosages will not induce higher responses. ${ }^{21,32,33)}$ Our previous CS studies also demonstrated these maximal response phenomena with no further stimulation by higher doses of CS and its fractions. ${ }^{15-20)}$ Thus, the present data was consistent with those findings without any unparalleled outcome. 
In conclusion, present study illustrated that CS and its fractions induced in vivo plasma corticosterone levels in immature and mature mice.

Acknowledgements This study was supported by the National Science Council (NSC93-2320-B-006-073) and Department of Health (DOH92-TD-1005), Taiwan, Republic of China, to BMH.

\section{REFERENCES}

1) Zhu J. S., Halpern G. M., Jones K., J. Alt. Comp. Med., 4, 289-303 (1998).

2) Zhu J. S., Halpern G. M., Jones K., J. Alt. Comp. Med., 4, 429-457 (1998).

3) Chiou W. F., Chang P. C., Chou C. J., Chen C. F., Life Sci., 66, 13691376 (2000).

4) Yamaguchi Y., Kagota S., Nakamura K., Shinozuka K., Kunitomo M., Phytotherapy Res., 14, 650-652 (2000).

5) Yoshida J., Takamura S., Yamaguchi N., Ren L. J., Chen H., Koshimura S., Suzuki S., Jap. J. Exp. Med., 59, 157-161 (1989).

6) Bok J. W., Lermer L., Chilton J., Klingeman H. G., Towers G. H., Phytochemistry, 51, 891-898 (1999).

7) Nakamura K., Yamaguchi Y., Kagota S., Kwon Y. M., Shinozuka K., Kunitomo M., Jap. J. Pharmacol., 79, 335-341 (1999).

8) Yang L. Y., Huang W. J., Hsieh H. G., Lin C. Y., J. Lab. Clin. Med., 141, 74-83 (2003).

9) Yang L. Y., Chen A., Kuo Y. C., Lin C. Y., J. Lab. Clin. Med., 134, 492-500 (1999).

10) Kuo Y. C., Tsai W. J., Wang J. Y., Chang S. C., Lin C. Y., Shiao M. S., Life Sci., 68, 1067-1082 (2001)

11) Weng S. C., Chou C. J., Lin L. C., Tsai W. J., Kuo Y. C., J. Ethnopharmacol., 83, 79-85 (2002).

12) Xu R. H., Peng X. E., Chen G. Z., Chen G. L., Chin. Med. J., 105, 97-101 (1992).

13) Kuo Y. C., Tsai W. J., Shiao M. S., Chen C. F., Lin C. Y., Am. J. Chin
Med., 24, 111-125 (1996).

14) Zhang Z., Xia S. S., J. Tongji Med. Univ., 10, 100-103 (1990).

15) Huang B. M., Chuang Y. M., Chen C. F., Leu S. F., Biol. Pharm. Bull., 23, 1532-1535 (2000).

16) Huang B. M., Ju S. Y., Wu C. S., Chuang W. J., Sheu C. C., Leu S. F., J. Androl., 22, 831-837 (2001).

17) Huang B. M., Hsu C. C., Tsai S. J., Sheu C. C., Leu S. F., Life Sci., 69, 2593-2602 (2001).

18) Hsu C. C., Tsai S. J., Huang Y. L., Huang B. M., FEBS Lett., 543, 140-143 (2003)

19) Hsu C. C., Huang Y. L., Tsai S. C., Sheu C. C., Huang B. M., Life Sci., 73, 2127-2136 (2003)

20) Huang Y. L., Leu S. F., Liu B. C., Sheu C. C., Huang B. M., Life Sci., 75, 1051-1062 (2004).

21) Wang S. M., Lee L. J., Lin W. W., Chang C. M., J. Cell Biochem., 69, 483-489 (1998).

22) Kirschner L. S., Ann. N.Y. Acad. Sci., 968, 222-239 (2002).

23) Huang B. M., Leu S. F., Yang H. Y., Norman R. L., J. Andrology, 22, 507-513 (2001).

24) Ranhotra H. S., Sharma R., Mech. Ageing Develop., 119, 15-24 (2000).

25) Miller D. B., O’Callaghan J. P., Ali S. F., Ann. N.Y. Acad. Sci., 914, 194-207 (2000).

26) Stone E. A., Quartermain D., Physiol. Behavior, 63, 143-145 (1997).

27) Bazhan N. M., Shevchenko A. Y., Karkaeva N. R., Yakovleva T. V., Makarova E. N., Eur. J. Endocrinol., 151, 265-270 (2004).

28) Patterson-Buckendahl P., Blakley G., Kubovcakova L., Krizanova O., Pohorecky L. A., Kvetnansky R., Ann. N.Y. Acad. Sci., 1018, 173182 (2004).

29) Harris R. B., Gu H., Mitchell T. D., Endale L., Russo M., Ryan D. H., Physiol. Behavior, 81, 557-568 (2004).

30) Moncek F., Duncko R., Johansson B. B., Jezova D., J. Neuroendocrinol., 16, 423-431 (2004).

31) Perello M., Moreno G., Gaillard R. C., Spinedi E., Neuroendocrinol. Lett., 25, 119-126 (2004).

32) Ascoli M., Endocrinology, 108, 88-95 (1981).

33) Saez J. M., Endocrine Rev., 15, 574-626 (1994). 